\title{
Rapid titrimetric and spectrophotometric methods for salbutamol sulphate in pharmaceuticals using $\mathrm{N}$-bromosuccinimide
}

\author{
KANAKAPURA BASAVAIAH ${ }^{1 *}$ \\ BANKAVADI CHIKKASWAMY SOMASHEKAR ${ }^{1}$ \\ VEERAIAH RAMAKRISHNA ${ }^{2}$ \\ ${ }^{1}$ Department of Chemistry, University \\ of Mysore, Manasagangotri \\ Mysore-570 006, India \\ ${ }^{2}$ Department of Pharmaceutical \\ Chemistry, Government College \\ of Pharmacy, Bangalore-27, India
}

One titrimetric and two spectrophotometric methods which are simple, sensitive and rapid are described for the assay of salbutamol sulphate (SBS) in bulk drug and in tablet dosage forms using $N$-bromosuccinimide (NBS) and two dyes, rhodamine-B and methylene blue, as reagents. In titrimetry, aqueous solution of salbutamol sulphate is treated with a measured excess of NBS in acetic acid medium and after the oxidation of SBS is complete, the unreacted oxidant is determined iodometrically. Spectrophotometric methods entail addition of a known excess of NBS in acid medium followed by the determination of residual oxidant by reacting with a fixed amount of either rhodamine $B$ and measuring the absorbance at $555 \mathrm{~nm}$ (method A) or methylene blue and measuring the absorbance at $665 \mathrm{~nm}$ (method B). In all methods, the amount of NBS reacting corresponds to the amount of SBS content. Titrimetric method is applicable over $1.74 \times 10^{-4}-8.68 \times 10^{-4} \mathrm{~mol} \mathrm{~L}^{-1}$ range and the reaction stoichiometry is found to be $1: 6$ (SBS:NBS). In spectrophotometric methods, the absorbance is found to increase linearly with the concentration of SBS, which is corroborated by the correlation of coefficients of 0.9993 and 0.9988 for method A and method B, respectively. The systems obey Beer's law for $0.25-1.75 \mu \mathrm{g} \mathrm{mL}^{-1}$ (method A) and $0.5-5.0 \mu \mathrm{g} \mathrm{mL}^{-1}$ (method B). The calculated apparent molar absorptivity values were found to be $2.10 \times 10^{5}$ and $6.16 \times 10^{4} \mathrm{~L} \mathrm{~mol}^{-1} \mathrm{~cm}^{-1}$, for method A and method B, respectively. The limits of detection and quantification are also reported for both spectrophotometric methods. Intraday and inter-day precision and accuracy for the developed methods were evaluated. The methods were successfully applied to the assay of SBS in tablet and capsule formulations and the results were statistically compared with those of a reference method. No interference was observed from common tablet adjuvants. The accuracy and reliability of the methods were further ascertained by recovery experiments via the standard-addition technique.

Keywords: salbutamol sulphate, assay, titrimetry, spectrophotometry, $\mathrm{N}$-bromosuccinimide

\footnotetext{
* Correspondence, e-mail: basavaiahk@yahoo.co.in
} 
Salbutamol sulphate (SBS) whose structure is given in Fig. 1 is a selective $\beta$-2-agonist antiasthmatic. Its primary action is to stimulate adenyl cyclase which catalyzes the formation of cyclic adenosin monophosphate. The drug is official in European Pharmacopoeia (1), which describes a potentiometric titration in non-aqueous medium, British Pharmacoeia (2) and Indian Pharmacopoeia (3). Some different methods of analysis have been reported for the determination of SBS, including HPLC (4-6) and UV-spectrophotometry $(7,8)$, but most of them require extensive sample preparation prior to the measurement step, some are less sensitive and some other are relatively complicated in terms of assay procedure or equipment required for analysis.

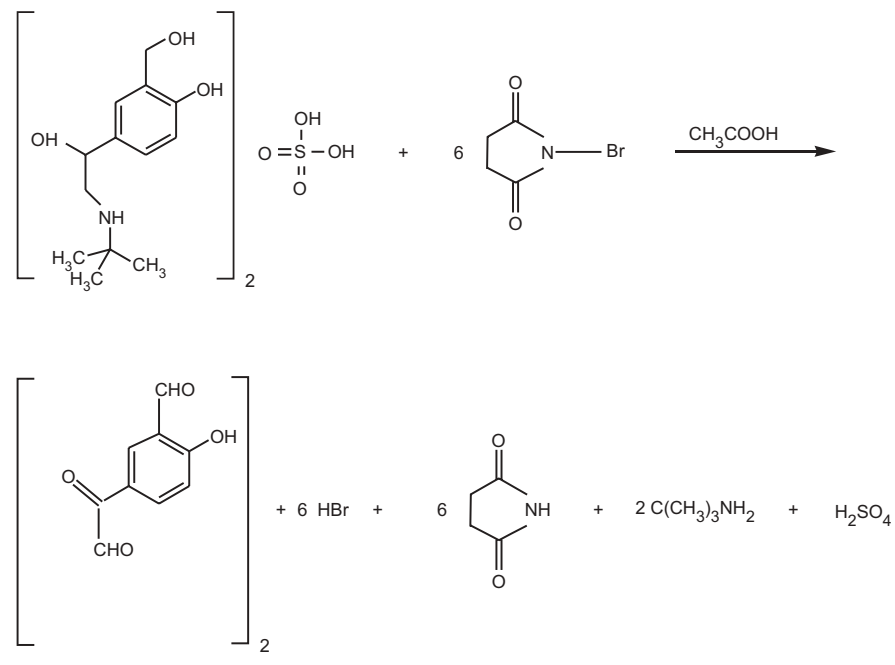

Fig. 1. Tentative reaction pathway.

SBS in pharmaceuticals has been assayed by visible spectrophotometric methods based on reactions such as redox $(9,10)$, reduction followed by chelation (11), oxidative coupling $(12,13)$, diazotization and coupling $(14,15)$, nitrosation (16), nitration (17), nitration followed by Meisenheiner complex formation (18) and charge-transfer complex formation (19). However, many of these procedures suffer from some disadvantage, such as poor sensitivity, heating or extraction step, critical working conditions or the use of organic solvents, and are hence unsatisfactory for routine analysis. The only visual titrimetric method (20) reported employs NBS as the oxidimetric titrant in the presence of potassium bromide and using methyl red as indicator. However, the method is applicable over a macro scale. Recently, Issa et al. (21) have reported a conductometric titration method using phosphotungstic and phosphomolybdic acids as titrants. Even these procedures are time consuming and less sensitive.

This paper describes three assay methods for SBS in tablets and capsules. The methods employ $\mathrm{N}$-bromosuccinimide as an oxidizing agent, rhodamine-B and methylene blue dyes as reagents. The proposed methods have the advantages of being rapid and simple 
K. Basavaiah et al.: Rapid titrimetric and spectrophotometric methods for salbutamol sulphate in pharmaceuticals using $N$-bromosuccinimide, Acta Pharm. 57 (2007) 87-98.

and are free from interferences from common tablet and capsule excipients. The results obtained were closely comparable to those of a reported method, and recovery tests were also found to be satisfactory.

\section{EXPERIMENTAL}

\section{Apparatus}

A Systronics Model 106 digital spectrophotometer (Systronics India Ltd., India) provided with 1-cm matched quartz cells was used for absorbance measurements.

Reagents and standard solutions. - All chemicals used were of analytical reagent grade and solutions were made in distilled water.

NBS solution $\left(0.01 \mathrm{~mol} \mathrm{~L}^{-1}\right)$ was prepared by dissolving $N$-bromosuccinimide (SRL Research Chemicals, India) in water with the aid of heat and standardized (22). The solution was kept in an amber coloured bottle stored in a refrigerator and used for titrimetry. It was diluted with water to get 70 and $150 \mu \mathrm{g} \mathrm{mL}{ }^{-1}$ NBS for use in spectrophotometric methods.

Sodium thiosulphate solution $\left(0.01 \mathrm{~mol} \mathrm{~L}^{-1}\right.$, Sisco Chem. Industries, India) was prepared in water and standardized. Potassium iodide (10\%) and starch (1\%) were prepared in the usual way. A stock solution of rhodamine B $\left(500 \mu \mathrm{g} \mathrm{mL}^{-1}\right)$ was prepared by dissolving the dye (s. d. Fine Chem. Ltd., India, dye content $80 \%$ ) in water and filtered using glass wool. The dye solution was diluted to $50 \mu \mathrm{g} \mathrm{mL}^{-1}$ for method A. $400 \mu \mathrm{g} \mathrm{mL}^{-1}$ methylene blue was prepared by dissolving the dye (s. d. Fine Chem., dye content $70 \%$ ) in water and filtered. It was diluted to $40 \mu \mathrm{g} \mathrm{mL}^{-1}$ with water and used in method $\mathrm{B}$.

Pharmaceutical grade SBS (certified to be $99.7 \%$ pure) was procured from Cipla India Ltd. (India) and was used as received. A stock standard solution equivalent to $1 \mathrm{mg}$ $\mathrm{mL}^{-1}$ SBS was prepared in water and was used in titrimetric work. This solution was appropriately diluted with water to yield working concentrations of 5 and $10 \mu \mathrm{g} \mathrm{mL}^{-1}$ for use in method A and method B, respectively.

\section{Assay procedures}

Titrimetry. - A 10-mL aliquot of pure drug solution containing 1.0-5.0 mg of SBS was accurately measured and transferred into a $100-\mathrm{mL}$ titration flask. The solution was acidified by adding $5 \mathrm{~mL}$ of $5 \mathrm{~mol} \mathrm{~L}^{-1}$ acetic acid followed by the addition of $10 \mathrm{~mL}$ of $0.01 \mathrm{~mol} \mathrm{~L}^{-1} \mathrm{NBS}$. The content was mixed well and the flask was kept aside for $15 \mathrm{~min}$ under occasional swirling. Then, $5 \mathrm{~mL}$ of $10 \%$ potassium iodide was added to the flask and the liberated iodine was titrated with $0.01 \mathrm{~mol} \mathrm{~L}^{-1}$ sodium thiosulphate to a starch end point. A blank titration was run under the same conditions.

Spectrophotometric method A. - Aliquots of pure SBS solution (0.5 to $3.5 \mathrm{~mL}, 5 \mu \mathrm{g}$ $\mathrm{mL}^{-1}$ ) were transferred into a series of $10-\mathrm{mL}$ calibrated flask and the total volume was adjusted to $4 \mathrm{~mL}$ with water. To each flask, $1 \mathrm{~mL}$ of $1 \mathrm{~mol} \mathrm{~L}^{-1}$ hydrochloric acid, was added, followed by $1 \mathrm{~mL}$ of NBS solution $\left(70 \mu \mathrm{g} \mathrm{mL}^{-1}\right)$. The contents were mixed and 
K. Basavaiah et al.: Rapid titrimetric and spectrophotometric methods for salbutamol sulphate in pharmaceuticals using $N$-bromosuccinimide, Acta Pharm. 57 (2007) 87-98.

the flasks were set aside for $10 \mathrm{~min}$ under occasional shaking. Finally, $1 \mathrm{~mL}$ of $50 \mu \mathrm{g}$ $\mathrm{mL}^{-1}$ rhodamine $B$ solution was added to each flask, diluted to the mark with water and the absorbance of solution was measured at $555 \mathrm{~nm}$ against a reagent blank after $10 \mathrm{~min}$.

Spectrophotometric method B. - Varying aliquots $(0.5-5.0 \mathrm{~mL})$ of standard $10 \mu \mathrm{g} \mathrm{mL} \mathrm{mL}^{-1} \mathrm{SBS}$ solution were accurately measured and delivered into a series of $10-\mathrm{mL}$ calibrated flasks, and the total volume was made up to $5.0 \mathrm{~mL}$ with water. To each flask, $1 \mathrm{~mL}$ each of 5 mol L-1 hydrochloric acid and $150 \mu \mathrm{g} \mathrm{mL}^{-1}$ NBS solution were added successively; the flasks were let stand for 10 min under occasional shaking. Then, $1 \mathrm{~mL}$ of $40 \mu \mathrm{g} \mathrm{mL}-1$ methylene blue solution was added to each flask, the volume was adjusted to the mark with water and mixed. The absorbance of each solution was measured at $665 \mathrm{~nm}$ against a reagent blank after 5 min.

In each spectrophotometric method, the concentration of the unknown was read from the calibration graph or computed from the regression equation derived from Beer's law data.

The limits of detection $(L O D)$ and quantification $(L O Q)$ were calculated according to the current ICH guidelines (23) using the following formulae:

$$
L O D=\frac{3.3 S D_{B}}{a} \text { and } L O Q=\frac{10 S D_{B}}{a}
$$

where $S D_{\mathrm{B}}$ is the standard deviation of seven reagent blank determinations and $a$ is the slope of the calibration curve.

\section{Procedure for tablets}

The following formulations containing SBS were purchased from local commercial sources and used in the investigation: A, Asthalin tablets, (Cipla India Ltd.) each containing 2/4 mg of SBS, B, Asmanil tablets, (Inga Pharmaceuticals, India) containing 2/4 $\mathrm{mg}$ of SBS per tablet, C. Bronkotab tablets, (GSK, India) containing 2/4 mg of SBS and D. Salbu capsules (Upjohn Pharm., India) containing 4/8 mg of SBS per capsule.

Fifty to 100 tablets or the contents of 50 capsules were accurately weighed and powdered. An amount of tablet/capsule powder equivalent to $100 \mathrm{mg}$ of SBS was accurately weighed into a $100-\mathrm{mL}$ calibrated flask, $60-\mathrm{mL}$ of water was added and shaken for 20 min. Then, the volume was diluted to the mark with water, the content was mixed well and filtered using a Whatman No. 42 filter paper. The first $10-\mathrm{mL}$ portion of the filtrate was discarded and a convenient aliquot (e.g., $3 \mathrm{~mL}$ ) of the subsequent portion was analyzed by titrimetry as described earlier. The filtrate $\left(1 \mathrm{mg} \mathrm{mL}^{-1}\right.$ in SBS) was diluted with water to obtain 5 and $10 \mu \mathrm{g} \mathrm{mL}^{-1}$ concentrations and subjected to spectrophotometric analysis as described above.

Recovery experiment. - To a fixed and known amount of drug in the tablet/capsule powder (pre-analysed), pure SBS was added at three different levels, and the total was found by the proposed methods, from which the percent recovery of pure drug added was calculated. 


\section{Selectivity testing}

A separate selectivity test was performed by applying the proposed methods to the determination of SBS in a synthetic mixture consisting of SBS (100 mg), talc $(250 \mathrm{mg})$, starch $(300 \mathrm{mg})$, lactose $(30 \mathrm{mg})$, calcium gluconate $(50 \mathrm{mg})$, calcium dihydrogenorthophosphate (20 mg), sodium alginate $(70 \mathrm{mg}$ ) and magnesium stearate $(100 \mathrm{mg})$, in the ratio of 1:2.5:3.0:0.3:0.5:0.2:0.7:1. SBS was extracted with three $20 \mathrm{~mL}$ portions of water and filtered. The filtrate was washed with water; the filtrate and washings were collected in a 100-mL calibrated flask and diluted to volume with water and mixed well. A convenient aliquot of the extract was subjected to analysis by titrimetry. The extract was suitably diluted to get 5 and $10 \mu \mathrm{g} \mathrm{mL}^{-1}$ solutions and was analyzed by spectrophotometric methods.

\section{RESULTS AND DISCUSSION}

The proposed methods are indirect and are based on the determination of surplus NBS after allowing the reaction between SBS and NBS as oxidant to occur. In titrimetry, the unreacted NBS is determined iodometrically, and in spectrophotometric methods, the same is determined by reacting with a fixed amount of either rhodamine-B or methylene blue. The latter methods make use of the bleaching action of NBS on either dye, the discolouration being caused by the oxidative destruction of the dye.

\section{Titrimetry}

The reaction stoichiometry that was used for all calculations was found to be 1:6. The relation between the amount of the drug and titration end point was examined. The linearity is apparent from the calculated correlation coefficient of -0.9954 and suggests that the reaction between SBS and NBS proceeds stoichiometrically in the ratio 1:6. Nonstoichiometric results were obtained in a hydrochloric acid medium as well as sulphuric acid medium. Quantitative results were obtained in an acetic acid medium and a $1.0 \mathrm{~mol} \mathrm{~L}^{-1}$ acetic acid concentration was found optimal although the reaction stoichiometry was unaffected in the range $0.2-2.0 \mathrm{~mol} \mathrm{~L}^{-1}$ acetic acid. The oxidation reaction was found to be complete and quantitative in $15 \mathrm{~min}$ and contact times up to $25 \mathrm{~min}$ had no effect on the stoichiometry and the results. Beyond $25 \mathrm{~min}$ and up to $60 \mathrm{~min}$, a small amount of NBS was consumed but without producing any definite stoichiometry. Hence, it is necessary to terminate the oxidation step at the end of the $15^{\text {th }}$ min to obtain accurate and precise results. A $10-\mathrm{mL}$ aliquot of $0.01 \mathrm{~mol} \mathrm{~L}^{-1} \mathrm{NBS}(0.1 \mathrm{mmol})$ solution was found adequate for quantitative oxidation of SBS in the range determined $0.1-0.5 \mathrm{mg} \mathrm{mL}^{-1}$.

\section{Spectrophotometry}

In the spectrophotometric methods, SBS was added to a fixed and known amount of NBS, and after the reaction was judged to be complete, residual NBS was determined by reacting with a fixed amount of either rhodamine B or methylene blue. SBS, when added in increasing amounts to a fixed amount of NBS, consumed the latter, and a con- 
K. Basavaiah et al.: Rapid titrimetric and spectrophotometric methods for salbutamol sulphate in pharmaceuticals using $N$-bromosuccinimide, Acta Pharm. 57 (2007) 87-98.

Table I. Intra-day accuracy and precision of the methods

\begin{tabular}{lccccc}
\hline Method & $\begin{array}{c}\text { SBS } \\
\text { taken }^{\mathrm{a}}\end{array}$ & $\begin{array}{c}\text { SBS } \\
\text { found }\end{array}$ & $\begin{array}{c}\mathrm{e}_{\mathrm{r}} \\
(\%)\end{array}$ & $\begin{array}{c}\text { RSD } \\
(\%)\end{array}$ & CL \\
\hline Titrimetry & 0.15 & 0.15 & 0.7 & 1.4 & $0.15 \pm 0.00_{2}$ \\
& 0.30 & 0.30 & 0.3 & 0.1 & $0.30 \pm 0.00$ \\
Spectrophotometric & 0.45 & 0.45 & 0.2 & 0.8 & $0.45 \pm 0.00_{4}$ \\
method A & 0.50 & 0.50 & 0.8 & 1.0 & $0.50 \pm 0.00_{5}$ \\
& 1.00 & 0.98 & 2.0 & 1.7 & $0.98 \pm 0.02$ \\
Spectrophotometric & 1.50 & 1.49 & 0.7 & 1.6 & $1.49 \pm 0.02$ \\
method B & 1.50 & 1.51 & 0.5 & 1.8 & $1.51 \pm 0.02$ \\
& 3.00 & 2.95 & 1.7 & 1.8 & $2.95 \pm 0.05$ \\
\hline
\end{tabular}

a In titrimetry, drug taken/found are in $\mathrm{mg} \mathrm{mL}^{-1}$, and in spectrophotometric methods $\mathrm{A}$ and $\mathrm{B}$ in $\mu \mathrm{g} \mathrm{mL}-1$.

$\mathrm{e}_{\mathrm{r}}$ - relative error.

CL - confidence limits at 95\% confidence level for six degrees of freedom.

comitant fall in NBS concentration occurred. When a fixed amount of either dye was reacted with decreasing amounts of NBS, a concomitant increase in the dye concentration occurred. This was observed as a proportional increase in the absorbance at the respective $\lambda_{\max }$ with increasing concentration of SBS, as shown by the correlation coefficients of $0.9993($ method A) and $0.9988($ method B).

Preliminary experiments were conducted to determine the maximum concentrations of rhodamine B and methylene blue spectrophotometrically by measuring the absorbance of their acidic solutions at their respective $\lambda_{\max }$, and the upper limits were found to be 5 and $4 \mu \mathrm{g} \mathrm{mL}^{-1}$ for rhodamine $\mathrm{B}$ and methylene blue, respectively. NBS concentration of $7 \mu \mathrm{g} \mathrm{mL}^{-1}$ was found to bleach the red colour due to $5 \mu \mathrm{g} \mathrm{mL} \mathrm{m}^{-1}$ rhodamine $\mathrm{B}$, whereas in the case of methylene blue $15 \mu \mathrm{g} \mathrm{mL}^{-1} \mathrm{NBS}$ was sufficient to destroy the blue colour of $4 \mu \mathrm{g} \mathrm{mL}^{-1}$ methylene blue. Hence, different amounts of SBS reacted with $7 \mu \mathrm{g}$ $\mathrm{mL}^{-1}$ NBS in method A and $15 \mu \mathrm{g} \mathrm{mL} \mathrm{mL}^{-1}$ NBS in method B before determining the residual NBS as described under the respective procedure.

Hydrochloric acid was found to be a convenient medium for the two steps involved in both methods. For a quantitative reaction between SBS and NBS, a contact time of 10 min was found sufficient in both methods. Constant absorbance readings were obtained when the reaction times were extended up to $20 \mathrm{~min}$ for method $\mathrm{A}$ and $30 \mathrm{~min}$ for method B and a standing time of 5-10 min was necessary for the bleaching of dye colour by the residual NBS. The measured colour was stable for several hours even in the presence of the reaction product.

\section{Quantitation parameters}

A linear correlation was found between absorbance at $\lambda_{\max }$ and SBS concentration and are described by the regression equations: 
K. Basavaiah et al.: Rapid titrimetric and spectrophotometric methods for salbutamol sulphate in pharmaceuticals using $N$-bromosuccinimide, Acta Pharm. 57 (2007) 87-98.

$$
\begin{aligned}
& \mathrm{A}=-0.0014+0.4114 \gamma ; R=0.9993, n=7(\operatorname{method} \mathrm{A}) \\
& \mathrm{A}=0.0047+0.1187 \gamma ; R=0.9998, n=10(\operatorname{method} \mathrm{B})
\end{aligned}
$$

where $\mathrm{A}$ is the absorbance and $\gamma$ is the concentration in $\mu \mathrm{g} \mathrm{mL}-1, R$ is the correlation coefficient and $n$ is the number of concentration levels. Beer's law is obeyed for $0.25-1.75$ and $0.5-5.0 \mu \mathrm{g} \mathrm{mL}^{-1}$ for method $\mathrm{A}$ and method $\mathrm{B}$, respectively. The calculated apparent molar absorptivity values were found to be $2.10 \times 10^{5}$ and $6.16 \times 10^{4} \mathrm{~L} \mathrm{~mol}^{-1} \mathrm{~cm}^{-1}$ for method A and method B, respectively.

\begin{tabular}{|c|c|c|c|c|c|}
\hline \multirow{3}{*}{$\begin{array}{l}\text { Formu- } \\
\text { lation }\end{array}$} & \multirow{3}{*}{$\begin{array}{l}\text { Nominal } \\
\text { amount } \\
\text { of SBS } \\
(\mathrm{mg})\end{array}$} & \multicolumn{4}{|c|}{ SBS found $(\%)^{a}$} \\
\hline & & \multirow{2}{*}{$\begin{array}{l}\text { Literature (9) } \\
\text { method }\end{array}$} & \multicolumn{3}{|c|}{ Proposed methods } \\
\hline & & & Titrimetry & $\begin{array}{l}\text { Spectrophoto- } \\
\text { metric method A }\end{array}$ & $\begin{array}{l}\text { Spectrophoto- } \\
\text { metric method B }\end{array}$ \\
\hline \multirow[t]{2}{*}{ A } & 2 & $98.7 \pm 0.9$ & $\begin{array}{c}97.3 \pm 1.3 \\
t=2.01 \\
F=2.09\end{array}$ & $\begin{array}{c}99.1 \pm 1.0 \\
t=0.67 \\
F=1.19\end{array}$ & $\begin{array}{c}100.0 \pm 1.2 \\
t=1.96 \\
F=1.78\end{array}$ \\
\hline & 4 & $99.1 \pm 0.8$ & $\begin{array}{c}100.9 \pm 1.2 \\
t=2.84 \\
F=2.25\end{array}$ & $\begin{array}{c}98.0 \pm 0.9 \\
\mathrm{t}=2.04 \\
F=1.27\end{array}$ & $\begin{array}{c}101.2 \pm 1.3 \\
t=3.16 \\
F=2.64\end{array}$ \\
\hline \multirow[t]{2}{*}{ B } & 2 & $98.7 \pm 1.1$ & $\begin{array}{c}99.9 \pm 1.0 \\
t=1.81 \\
F=1.21\end{array}$ & $\begin{array}{c}98.0 \pm 1.0 \\
t=1.05 \\
F=1.21\end{array}$ & $\begin{array}{c}97.0 \pm 1.3 \\
t=2.24 \\
F=1.40\end{array}$ \\
\hline & 4 & $97.8 \pm 1.2$ & $\begin{array}{c}98.7 \pm 1.0 \\
t=1.29 \\
F=1.44\end{array}$ & $\begin{array}{c}99.1 \pm 1.3 \\
t=1.64 \\
F=1.17\end{array}$ & $\begin{array}{c}100.1 \pm 1.1 \\
t=3.16 \\
F=1.19\end{array}$ \\
\hline \multirow[t]{2}{*}{ C } & 2 & $99.3 \pm 0.9$ & $\begin{array}{c}101.2 \pm 1.1 \\
t=3.00 \\
F=1.49\end{array}$ & $\begin{array}{c}100.6 \pm 1.1 \\
t=2.05 \\
F=1.49\end{array}$ & $\begin{array}{c}97.1 \pm 1.0 \\
t=3.66 \\
F=1.23\end{array}$ \\
\hline & 4 & $100.7 \pm 1.1$ & $\begin{array}{c}99.1 \pm 1.0 \\
t=2.41 \\
F=1.21\end{array}$ & $\begin{array}{c}98.6 \pm 1.4 \\
t=2.65 \\
F=1.62\end{array}$ & $\begin{array}{c}102.05 \pm 1.1 \\
t=1.94 \\
F=1.00\end{array}$ \\
\hline \multirow[t]{2}{*}{$\mathrm{D}$} & 4 & $101.4 \pm 0.7$ & $\begin{array}{c}100.1 \pm 1.1 \\
t=2.28 \\
F=2.47\end{array}$ & $\begin{array}{c}102.3 \pm 1.3 \\
t=1.42 \\
F=3.45\end{array}$ & $\begin{array}{c}99.8 \pm 1.3 \\
t=2.53 \\
F=3.45\end{array}$ \\
\hline & 8 & $100.3 \pm 1.5$ & $\begin{array}{c}98.9 \pm 1.4 \\
t=1.53 \\
F=1.15\end{array}$ & $\begin{array}{c}99.3 \pm 0.9 \\
t=1.32 \\
F=2.78\end{array}$ & $\begin{array}{c}101.8 \pm 1.0 \\
t=1.90 \\
F=2.25\end{array}$ \\
\hline
\end{tabular}

Table II. Assay of formulations by the proposed methods

\footnotetext{
a Mean $\pm \mathrm{SD}, n=5$.
} 
K. Basavaiah et al.: Rapid titrimetric and spectrophotometric methods for salbutamol sulphate in pharmaceuticals using $N$-bromosuccinimide, Acta Pharm. 57 (2007) 87-98.

Table III. Recovery study ${ }^{a}$

\begin{tabular}{lcccr}
\hline Method & $\begin{array}{c}\text { SBS in } \\
\text { formulation }\end{array}$ & $\begin{array}{c}\text { SBS } \\
\text { added }\end{array}$ & $\begin{array}{c}\text { Total SBS } \\
\text { found }\end{array}$ & $\begin{array}{c}\text { SBS recovered } \\
(\%)^{\mathrm{b}}\end{array}$ \\
\hline Titrimetrya $^{\mathrm{a}}$ & 0.15 & 0.10 & 0.24 & $97.5 \pm 1.6$ \\
& 0.15 & 0.20 & 0.34 & $99.2 \pm 2.1$ \\
& 0.15 & 0.30 & 0.45 & $101.1 \pm 1.3$ \\
Spectrophotometric & 0.50 & 0.40 & 0.90 & $98.5 \pm 2.6$ \\
method A & 0.50 & 0.80 & 1.27 & $96.6 \pm 3.2$ \\
& 0.50 & 1.20 & 1.69 & $99.3 \pm 2.7$ \\
Spectrophotometric & 2.00 & 1.00 & 3.02 & $102.1 \pm 2.3$ \\
method Ba & 2.00 & 2.00 & 4.09 & $104.5 \pm 4.1$ \\
& 2.00 & 3.00 & 4.94 & $97.9 \pm 3.7$ \\
\hline
\end{tabular}

In titrimetry, SBS in formulation, added and total found, are in $\mathrm{mg} \mathrm{mL}^{-1}$, and in spectrophotometric methods $\mathrm{A}$ and $\mathrm{B}$, in $\mu \mathrm{g} \mathrm{mL}^{-1}$.

a Studied formulation tablet A, $2 \mathrm{mg}$ SBS.

${ }^{\mathrm{b}}$ Mean $\pm \mathrm{SD}, n=3$.

\section{Precision and accuracy}

Intra-day precision was assessed from the results of seven replicate analyses on pure drug solution. The mean values and relative standard deviation (RSD) values for replicate analyses at three different levels (amounts/concentrations) were calculated. To evaluate the inter-day precision, analysis was performed over a period of five days, preparing all solutions afresh each day.

The accuracy of the methods was determined by calculating the percentange deviation observed in the analysis of pure drug solution and expressed as the relative error. Table I summarizes the intra-day precision and accuracy data for the assay of SBS in pure drug solution by the proposed methods and they were within $2.0 \%$. The inter-day RSD was $\leq 2.4 \%$.

\section{Application to dosage forms}

The proposed methods were applied to the analysis of SBS in tablets and capsules and the results were statistically compared with those obtained by the reported method (9), which consisted of measuring the absorbance of blue chromogen at $670 \mathrm{~nm}$ after treating tablet extract with Folin-Ciocalteau reagent in alkaline medium. The calculated $t$ and $F$-values were lower than the tabulated values at $95 \%$ confidence level, revealing that the proposed methods and the reference method have similar accuracy and precision. In a few cases the $t$-calculated values are deviant and this can be ascribed to random errors.

From the recovery experiment, it was found that the percent recovery of the pure drug added to tablet/capsule powder ranged from 97.5 to 104.5, as shown in Table III, 
K. Basavaiah et al.: Rapid titrimetric and spectrophotometric methods for salbutamol sulphate in pharmaceuticals using $N$-bromosuccinimide, Acta Pharm. 57 (2007) 87-98.

Table IV. Comparison of reported spectrophotometric methods with the proposed method for the assay of SBS

\begin{tabular}{|c|c|c|c|c|c|}
\hline Reagent(s) used & $\lambda_{\max }(\mathrm{nm})$ & $\begin{array}{l}\text { Beer's law } \\
\text { limits } \\
\left(\mu \mathrm{g} \mathrm{mL} \mathrm{mL}^{-1}\right)\end{array}$ & $\begin{array}{c}\text { Molar } \\
\text { absorptivity } \\
\left(\mathrm{L} \mathrm{mol}^{-1} \mathrm{~cm}^{-1}\right)\end{array}$ & Remarks & Reference \\
\hline $\begin{array}{l}\text { Folin-Ciocalteau re- } \\
\text { agent }\end{array}$ & 760 & $0.0-6.0$ & - & - & 4 \\
\hline $\begin{array}{l}\text { Folin-Ciocalteau re- } \\
\text { agent }\end{array}$ & 750 & $1-15$ & - & $\begin{array}{l}\text { on-line solid phase } \\
\text { extraction and flow } \\
\text { injection }\end{array}$ & 5 \\
\hline $\begin{array}{l}\text { Iron(III)-1,10 - } \\
\text { phenanthroline }\end{array}$ & 510 & $400-4000$ & - & & 6 \\
\hline $\begin{array}{l}\text { Ferricyanide-4- } \\
\text { aminophenazone }\end{array}$ & 505 & $25-175$ & - & $\begin{array}{l}\text { heating, waiting time } \\
30 \mathrm{~min}\end{array}$ & 7 \\
\hline Cerium(IV)/MBTH & 530 & upto 15 & $2.4 \times 10^{4}$ & $\begin{array}{l}\text { extraction, expensive } \\
\text { reagent }\end{array}$ & 8 \\
\hline $\mathrm{NaNO}_{2} / \mathrm{PHSA}$ & 440 & upto 10 & - & - & 9 \\
\hline $\begin{array}{l}\mathrm{NaNO}_{2} / 3 \text {-amino } \\
\text { pyridine }\end{array}$ & 440 & $1-10$ & - & - & 10 \\
\hline $\mathrm{NaNO}_{2}$ & 410 & $5-60$ & - & boiling, $30 \mathrm{~min}$ & 11 \\
\hline $\mathrm{KNO}_{3} / \mathrm{H}_{2} \mathrm{SO}_{4}$ & 420 & $0-48$ & - & boiling, $30 \mathrm{~min}$ & 12 \\
\hline $\begin{array}{l}\mathrm{HNO}_{3} / \mathrm{H}_{2} \mathrm{SO}_{4} / \\
\text { Meisenheimer complex } \\
\text { formation }\end{array}$ & 386 & $4.8-16.0$ & - & boiling, $20 \mathrm{~min}$ & 13 \\
\hline DCQC & & $1-30$ & - & organic solvent & 14 \\
\hline TCNQ & & $2-20$ & - & organic solvent & 14 \\
\hline NBS/rhodamine B & 555 & $0.125-1.75$ & $2.10 \times 10^{5}$ & & this paper \\
\hline NBS/methylene blue & 665 & $0.5-5.0$ & $6.16 \times 10^{4}$ & & this paper \\
\hline
\end{tabular}

MBTH - 3-methyl-benzothiazolin-2-one hydrazone

PHSA - phenylhydrazine sulphonic acid

DCQC - 2,6-dichloroquinone chlorimide

TCNQ - 7,7,8,8-tetracyanoquinodimethane

and that neither the end point detection in titrimetry nor absorbance measurement in spectrophotometry was affected by tablet excipients such as talc, starch, lactose, magnesium stearate, sodium alginate, calcium gluconate and calcium dihydrogenorthophosphate.

The recovery of SBS in selectivity testing was found to be $103.5 \pm 1.3,102.8 \pm 1.8$ and $101.7 \pm 1.3$ for titrimetric, spectrophotometric method A and method B, respectively.

The proposed methods are simple, rapid and reliable compared to most existing methods. In contrast to the direct titration method (16) reported earlier, the proposed method is more sensitive with a determinable range of $0.1-0.5 \mathrm{mg} \mathrm{mL}^{-1}\left(1.73 \times 10^{-4}\right.$ $8.68 \times 10^{-4} \mathrm{~mol} \mathrm{~L}^{-1}$ ) and can be applied to a single tablet or capsule so that tablet to tab- 
let or capsule to capsule variation, if desirable, can be followed. The methods are accurate to -3.0 to $+2.3 \%$ when applied to the determination of SBS in formulations and the relative standard deviation varied from 0.9 to $1.4 \%$. The selectivity as determined from accuracy estimation $(+1.7$ to $+3.5 \%)$ was good; in the recovery study via the standard addition method accuracy ranged from -2.5 to $+4.5 \%$. Even precisionwise, the selectivity data show comparable RSDS to that of recovery experiments, $1.3-1.8$ vs. $1.6-4.1 \%$. The performance characteristics of the existing spectrophotometric methods and the present methods are given in Table IV, from which it is obviously clear that the proposed methods are free from drastic experimental conditions such as heating or extraction step unlike many reported procedures. Both methods are highly sensitive compared to all the existing spectrophotometric methods, as shown by the molar absorptivity values; and in fact, the method using rhodamine B is the most sensitive one ever reported for salbutamol. Further, both methods are based on the ultimate measurement of dye colour, which is found to be exceptionally stable under the described experimental conditions, and the measurement is made at longer wavelengths where the interference from the excipients is far less compared to shorter wavelengths used in many reported procedures. The proposed methods use eco-friendly and inexpensive chemicals and seldom employ organic solvents.

\section{CONCLUSIONS}

In conclusion, the results of the assay demonstrate that the proposed methods can be used to determine the content uniformity of tablets and capsules, as well as the purity of salbutamol raw material. Besides the simplicity of the procedures, the relative cheapness of apparatus demonstrates their advantageous characteristics in addition to their high accuracy and precision. The spectrophotometric methods described in the present work have the clear advantages of sensitivity comparable to that achieved by an expensive technique like HPLC. Applicability of spectrophotometric to the determination of salbutamol in urine and blood samples, of course, after appropriate sample pretreatment, will be the topic of our further research.

Acknowledgements. - The authors gratefully acknowledge the gift of pure salbutamol sulphate from Cipla India Ltd, Mumbai, India. Two of the authors (BCS \& VRK) thank the authorities of the University of Mysore, Mysore, for research facilities. VRK is grateful to the Principal Secretary, Department of Health and Family Welfare, Government of Karnataka, Bangalore.

\section{REFERENCES}

1. European Pharmacopoeia, 5 ${ }^{\text {th }}$ ed., vol. II, EDQM, Strasbourg 2005, p. 3611.

2. The British Pharmacopoea, Her Majesty's Stationery Office, London 1998, pp. 1151-1152.

3. Indian Pharmacopoea, The Controller of Publications, Ministry of Health and Family Welfare, Government of India, New Delhi 1996, pp. 670-673.

4. T. L. Bernal, M. J. del-Nozal, H. Velasco and L. Toribio, HPLC versus SFC for the determination of salbutamol sulphate and its impurities in pharmaceuticals, J. Liq. Chromatogr. Rel. Technol. 19 (1996) 1579-1589. 
K. Basavaiah et al.: Rapid titrimetric and spectrophotometric methods for salbutamol sulphate in pharmaceuticals using $N$-bromosuccinimide, Acta Pharm. 57 (2007) 87-98.

5. S. Ray and A. Bandopadhyay, Reversed phase high performance liquid chromatographic determination of salbutamol sulphate in pharmaceutical formulations, Indian Drugs 27 (1990) 313316.

6. R. A. Singh, Kumar, D. Kumar and A. K. Agarwal, Simultaneous estimation of cetirizine hydrochloride and salbutamol sulphate in pharmaceutical dosage forms by reverse phase high performance liquid chromatography, Pharma Rev. 3 (2005) 144-146.

7. N. Talwar, A. K. Singhai, A. K. Shakya, S. Saraf and N. K. Jain, Difference spectrophotometric determination of salbutamol sulphate in tablets, Indian Drugs 28 (1991) 244-245.

8. I. H. I. Habib, M. E. M. Hassouna and G. A. Zaki, Simultaneous spectrophotometric determination of salbutamol and bromhexin in tablets, Farmaco 60 (2005) 249-254.

9. N. P. Sadler and H. Jacobs, Application of the Folin-Ciocalteau reagent to the determination of salbutamol in pharmaceutical preparations, Talanta 42 (1995) 1385-1388.

10. D. Satinsky, R. Karlicek and A. Svaboda, Using on-line solid phase extraction for flow injection spectrophotometric determination of salbutamol, Anal. Chim. Acta 455 (2002) 103-109.

11. M. N. Reddy, D. G. Sankar, G. D. Rao and K. Sreedhar, Spectrophotometric determination of salbutamol and terbutaline, East. Pharm. 34 (1991) 127-128.

12. M. Basu and B. Pathak, Estimation of salbutamol sulphate in pharmaceutical formulations, Indian Drugs 28 (1990) 109-110.

13. N. Geetha and T. R. Baggi, Improved spectrophotometric method for the determination of salbutamol sulphate with 3-methyl benzothiazolin-2-one hydrazone, Microchem. J. 39 (1989) 137144.

14. N. V. Naidu, D. V. Naidu, C. V. Rajeshwari and P. R. Naidu, Simple spectrophotometric determination of salbutamol sulphate in pharmaceutical formulations, Acta Chim. Hung. 126 (1989) 821-824.

15. K. K. Vishwanth, A. S. Rao and M. V. Shivaramakrishnan, Colorimetric determination of salbutamol in pharmaceutical preparations, Indian Drugs 26 (1989) 516-518.

16. R. B. Patel, A. S. Patel and U. Pallavi, Spectrophotometric determination of salbutamol sulphate and its combination in pharmaceutical dosage forms, Indian Drugs 24 (1987) 298-302.

17. N. M. Sanghavi and J. T. Vyas, Use of nitrating agent in the colorimetric estimation of drugs Part II, Indian Drugs 34 (1997) 463-466.

18. R. S. Bakry, A. F. El-Walily and S. F. Belal, Spectrophotometric determination of etilefrine, ritodrine, isoxsuprine and salbutamol by nitration and subsequent Meisenheimer complex formation, Anal. Lett. 28 (1995) 2503-2519.

19. G. G. Mohammed, S. M. Khalil, M. A. Zayed and M. Abd El-Hamid El-Shall, 2,6-Dichloroquinone chlorimide and 7,7,8,8-tetracyanoquino-dimethane reagents for the spectrophotometric determination of salbutamol in pure and dosage forms, J. Pharm. Biomed. Anal. 28 (2002) 11271137.

20. N. Geetha and T. R. Baggi, Microtitrimetric determination of salbutamol sulphate using N-bromosuccinimide, Mikrochim. Acta 1990, 95-99.

21. Y. M. Issa, A. F. Shoukry and R. M. El-Nashar, Conductometric determination of reproterol $\mathrm{HCl}$ and pipazethate $\mathrm{HCl}$ and salbutamol sulphate in their pharmaceutical formulation, J. Pharm. Biomed. Anal. 26 (2002) 379-386.

22. A. Berka, J. Vulterin and J. Zyka, Newer Redox Titrants, Pergamon Press, New York 1965, pp. 53.

23. International Conference on Harmonisation of Technical Requirements for Registration of Pharmaceuticals for Human Use, ICH Harmonised Tripartite Guideline, Validation of Analytical Procedures: Text and Methodology Q2(R1), Complementary Guideline on Methodology dated 06 November 1996, incorporated in November 2005, London. 
K. Basavaiah et al.: Rapid titrimetric and spectrophotometric methods for salbutamol sulphate in pharmaceuticals using $N$-bromosuccinimide, Acta Pharm. 57 (2007) 87-98.

\section{$S A \check{Z} E T A K$}

\section{Brze titrimetrijske i spektrofometrijske metode za određivanje salbutamol sulfata koristeći $\mathrm{N}$-bromsukcinimid}

KANAKAPURA BASAVAIAH, BANKAVADI CHIKKASWAMY SOMASHEKAR i VEERAIAH RAMAKRISHNA

U radu su opisane jedna titrimetrijska i dvije spektrofotometrijske metode za određivanje salbutamol sulfata (SBS) čiste tvari i u tabletama. Opisane metode su jednostavne, osjetljive i brze, a kao reagense koriste $N$-bromsukcinimid (NBS) i dva bojila, rodamin-B i metilensko modrilo. U titrimetrijskoj metodi, vodenoj otopini salbutamol sulfata dodana je otopina NBS-a u octenoj kiselini u suvišku, te je nakon potpune oksidacije SBS-a jodometrijski određena količina neizreagiranog oksidansa. U spektrofotometrijskim metodama dodaje se poznati suvišak NBS-a u kiselom mediju nakon čega se neizreagirani suvišak oksidansa određuje nakon reakcije s rodaminom-B mjereći apsorbanciju na 555 nm (metoda A) ili metilenskim modrilom mjereći apsorbanciju na $665 \mathrm{~nm}$ (metoda B). U svim metodama, količina NBS-a koji reagira ekvivalentna je sadržaju SBS-a. Titrimetrijska metoda je primjenjiva u rasponu koncentracija od $1,74 \times 10^{-4}$ do $8,68 \times 10^{-4} \mathrm{~mol} \mathrm{~L}^{-1}$. SBS i NBS reagiraju u stehiometrijskom omjeru 1:6. U spektrofotometrijskim metodama apsorbancija linearno raste s koncentracijom SBS-a, što je potvrđeno koeficijentima korelacije od 0,9993 za metodu A te 0,9988 za metodu B. Sustavi slijede Beer-ov zakon unutar koncentracija $0,25-1,75 \mu \mathrm{g} \mathrm{mL}^{-1}$ (metoda A) i $0,5-5,0 \mu \mathrm{g} \mathrm{mL}-1$ (metoda B). Izračunate vrijednosti molarnog apsorpcijskog koeficijenta iznose $2,10 \times 10^{5}$ za metodu A i $6,16 \times$ $10^{4} \mathrm{~L} \mathrm{~mol}^{-1} \mathrm{~cm}^{-1}$ za metodu B. Granice detekcije i kvantifikacije, ispravnost i preciznost (ponovljivost i intermedijarska preciznost) ponovljivost su za obje spektrofotometrijske metode. Metode su uspješno primijenjene za analizu SBS-a u tabletama i kapsulama, a rezultati su statistički uspoređeni s referentnom metodom. Uobičajene pomoćne tvari u tabletama nisu interferirale tijekom određivanja. Ispravnost metoda potvrđena je i metodom standardne adicije.

Ključne riječi: salbutamol sulfat, analiza, titrimetrija, spektrofotometrija, $N$-bromsukcinimid

Department of Chemistry, University of Mysore, Manasagangotri, Mysore-570 006, India

Department of Pharmaceutical Chemistry, Government College of Pharmacy, Bangalore-27, India 